This is an Accepted Manuscript of an article published by Wiley Blackwell in the International Journal of Nautical Archaeology on 10 August, 2012. The published version is available online at DOI: 10.1111/j.1095-9270.2012.00349.x .Please use it in any citations.

\title{
A stone anchor from the Farasan Islands, Saudi Arabia.
}

A recent rapid archaeological survey of the three main islands of the Farasan archipelago has identified a large, three-holed stone anchor that is the first in an on-land context to be reported from Saudi Arabia.

The Farasan archipelago lies off the Arabian shore of the southern Red Sea, some $50 \mathrm{~km}$ from Jizan, the Saudi port town from which it is today reached (Fig. 1). Most of islands - more than 140 - are in Saudi territory, while the southernmost extend into Yemen. Three of the larger islands - Greater Farasan, Segid and Qumah - are inhabited. The islands' geology comprises elevated fossil-coral plateaux that reach a maximum altitude of $70 \mathrm{~m}$, giving rise to a largely flat, arid terrain cut through with occasional shallow wadis on the larger islands, and areas of coral-sand dunes and plains. The climate is hot and arid, with mean annual rainfall at the nearest weather station in Jizan measuring $129 \mathrm{~mm} / \mathrm{yr}$ (Hall et al., 1998: 191). Limited arable and date-palm cultivation occurs in some wadis. Wells, many probably in use since antiquity, occur at several locations around Greater Farasan and Segid. The presence of accessible groundwater must have represented an attractive source of water for ships navigating the southern Red Sea in the past (Cooper and Zazzaro, forthcoming). Moreover, medieval and modern pilot guides suggest that the eastern side of the Red Sea has long been favoured for northward sailing in the region (Tibbetts, 1971: 259; Davies and Morgan, 2002: 121), further placing the islands as a convenient stop-over for ships. The Martyrium of St Arethas says that a naval fleet was based on the islands in the early 6th century AD (Van Hecke et al. 1861: 747). The political allegiance of this fleet is unknown.

The stone anchor (Fig. 2) was recorded during a preliminary archaeological assessment survey of the islands of Greater Farasan, Segid and Qumah, conducted alongside a wider ethnographic survey by members of the University of Exeter's MARES Project (Cooper and Zazzaro, forthcoming; Agius, Cooper, et al, forthcoming). The archaeological sites visited and logged during the survey include settlements, wells, cemeteries, and a rock-cut cave, only few of which have been published previously, and then only briefly (Zarins et al., 1981: 27). The only other published archaeological work on the islands has focused on prehistoric human exploitation of the marine environment (Bailey et al. 2007a, 2007b). The MARES 
fieldwork included the recording of the location of the sites with a hand-held GPS unit; site photography; sketch-mapping; and a preliminary assessment of surface ceramics. The latter, together with already reported ancient South Arabian and Roman epigraphic evidence from sites across the main island, point to multiple periods of occupation ranging from the first half of the 1st millennium BC to the present era, and suggest contact with ancient South Arabia, East Africa and the Aksumite kingdom, the Roman world, Persia the Far East and, more recently, the Netherlands (Cooper and Zazzaro, forthcoming; Marion de Procé and Phillips, 2010; Phillips et al., 2004; Villeneuve, 2004, 2007a, 2007b, 2008; Villeneuve et al., 2004).

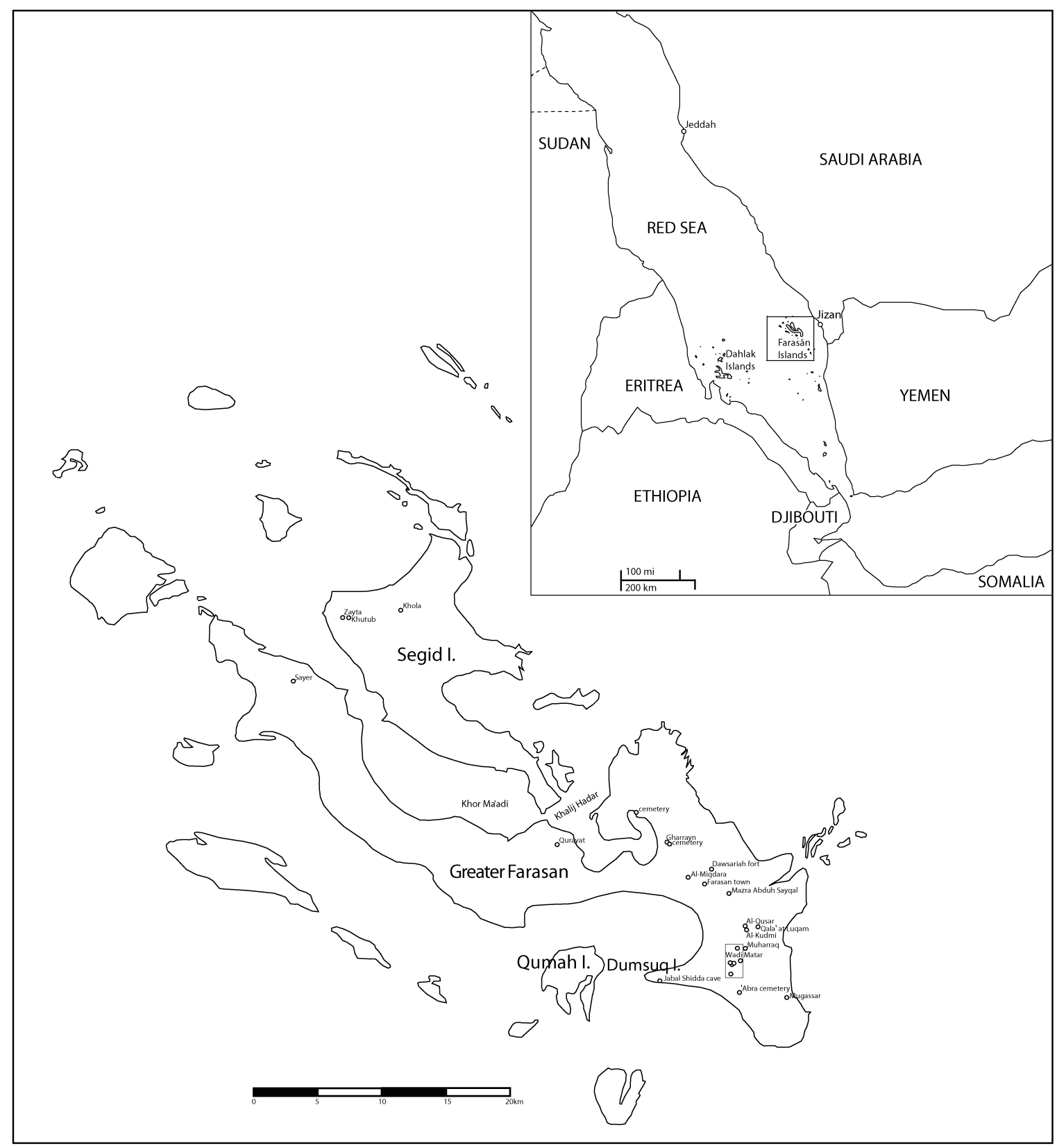

Figure 1. The survey area: Wadi Matar, Farasan Islands, Saudi Arabia. 


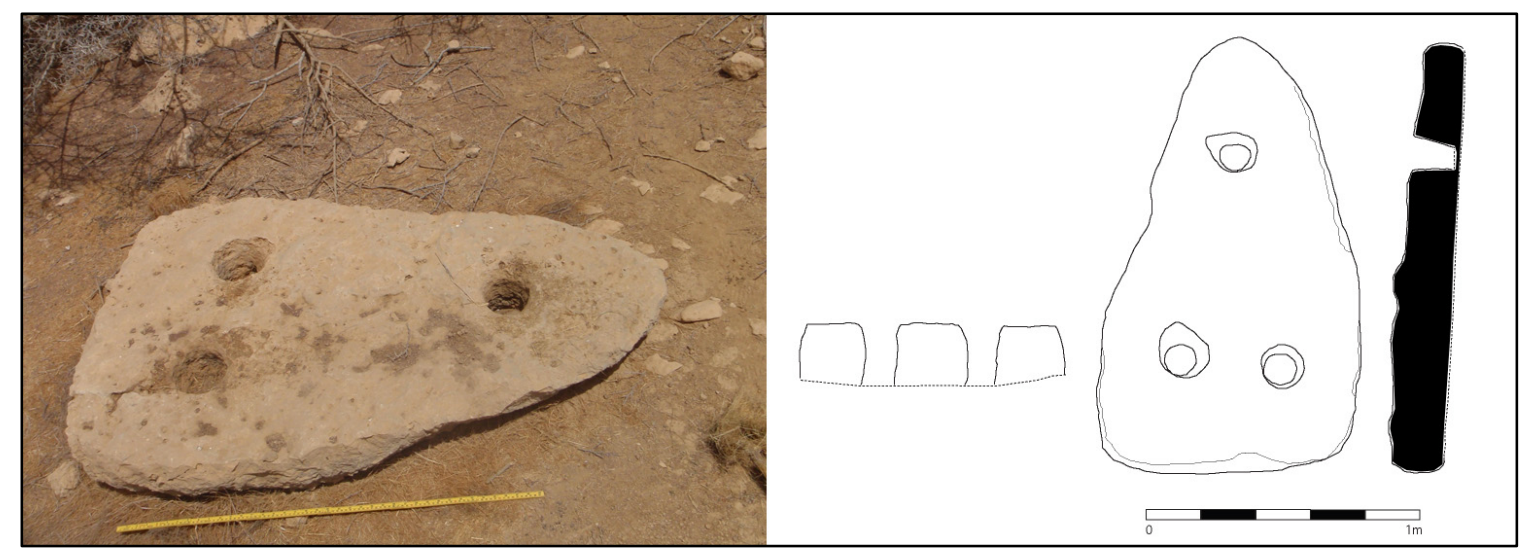

Figure 2. The Wadi Matar stone anchor. The scale in the photograph is $1 \mathrm{~m}$. (The authors; drawing assisted by Lucy Semaan)

\section{The anchor}

While many of the archaeological remains encountered on the islands imply past maritime connections with overseas locations and societies, only one discovery - the large stone anchor reported here - provides direct evidence of the nautical technology employed.

The anchor was found on land, some $2.6 \mathrm{~km}$ from the nearest contemporary shoreline, on a plateau alongside the Wadi Matar in the southeast of Greater Farasan island (Fig. 1). It was found on the surface on the eastern periphery of Wadi Matar $B \bar{a}^{\supset}(\varphi)$, one of the four sites on the plateau previously identified by Zarins, Murad and Al-Yish (1981: 27), and labelled with letters of the Arabic alphabet - the others sites being Wadi Matar Alif(I), $H \bar{a}^{\rho}(\tau)$ and Jim (ج).

The anchor was found lying flat, with one face on the ground, and its upper face, sides and holes exposed. It was too heavy to be lifted with the resources available to the survey, and the observations made here are therefore on the basis of what was apparent. The anchor is broadly in the shape of an isosceles triangle with rounded corners, measuring $153 \mathrm{~cm}$ long and $85 \mathrm{~cm}$ wide at its short edge, with a thickness of $c .20 \mathrm{~cm}$ (Fig. 2). It has three holes pierced through it, each measuring between 11 and $15 \mathrm{~cm}$ in diameter. Two are near the short edge, the anchor's base, and probably held wooden flukes. The third is near the apex, and would have secured the hauling rope. The anchor appears to have been made from the same fossil-coral rock that forms the main substrate of the islands, and which was used in the masonry of the visible building remains in the Wadi Matar. Tool-marks visible on the edges of the anchor 
suggest that it has been shaped from a flat slab, the sides being cut using a metal implement. No tool marks were visible on the top surface. The holes themselves appeared to have been carved through in one direction from one side to the other, using a metal chisel.

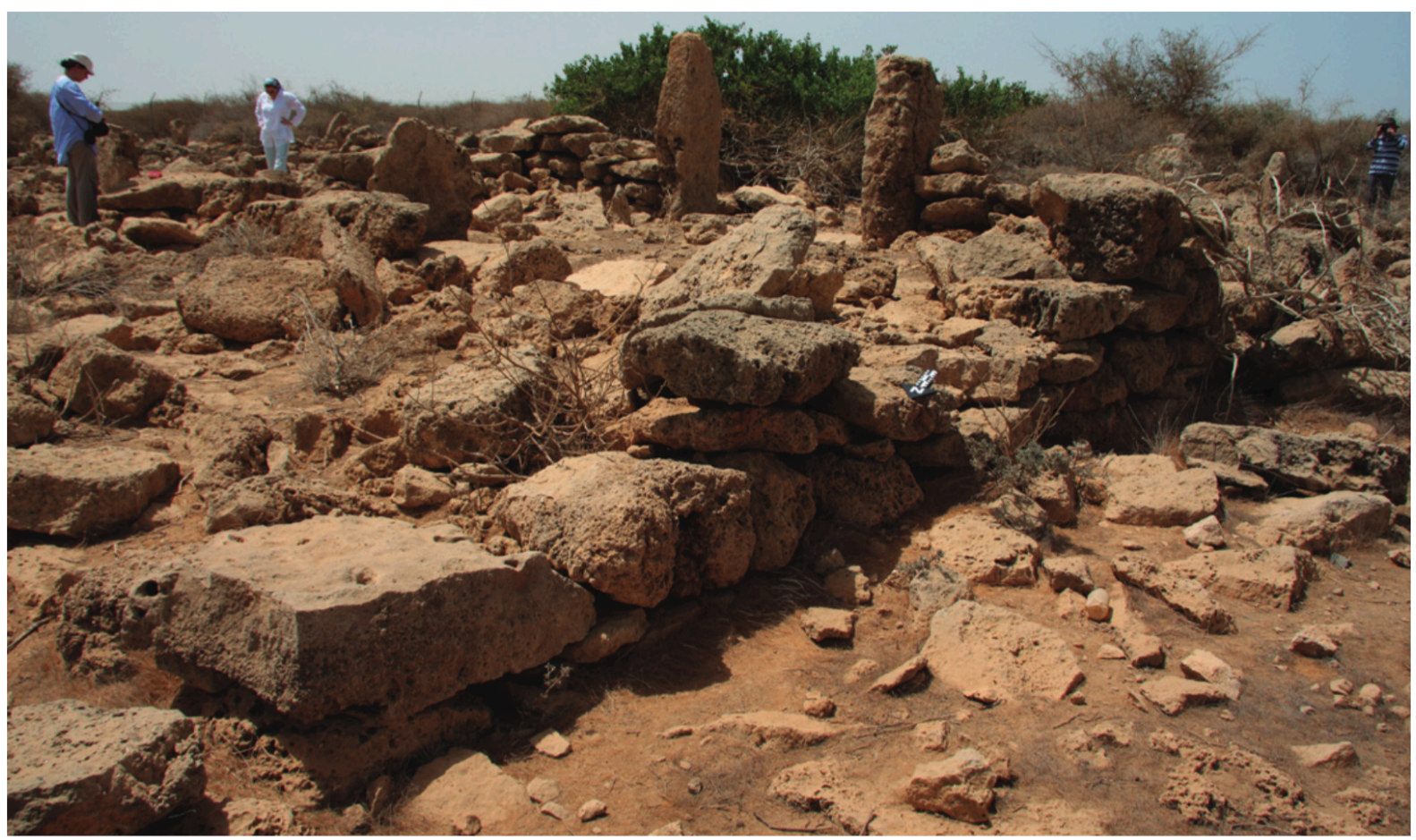

Figure 3. A general view of the Wadi Matar $\mathrm{B} \bar{a}^{j}$ site, on which the anchor was found (John P. Cooper).

\section{The anchor in its archaeological context}

The Wadi Matar $B \bar{a}^{\text {s }}$ site comprises the remains of a relatively dense group of interconnected fossil-coral stone buildings covering an area of some $110 \mathrm{~m}$ by $200 \mathrm{~m}$ (Fig. 3). The buildings were characterized by rubble-stone walls standing up to $0.5 \mathrm{~m}$ high, with doorways oriented in the cardinal directions. These characteristic doorways - fifteen in total - were observed to have the same construction as buildings at other sites on the plateau, as well as elsewhere on the islands: the two dressed-stone doorposts of each doorway ranged from $c .50-185 \mathrm{~cm}$ in height, $15-44 \mathrm{~cm}$ in depth, and 56-92 $\mathrm{cm}$ in width at the base, sometimes tapering towards the top. Each doorway also had a flat threshold slab measuring c. 90-102 cm in width and 30-73 $\mathrm{cm}$ in depth (Cooper and Zazzaro, forthcoming).

Dating indicators, mainly ceramic and epigraphic, point to a broadly pre-Islamic date for most of the Wadi Matar sites, including Wadi Matar $B \bar{a}^{\text {. }}$. The doorway of one building at the latter site comprised two large facing monolithic slabs (measuring respectively 183 x 56 x $40 \mathrm{~cm}$ 
and $170 \times 74 \times 37 \mathrm{~cm}$ ), roughly rectangular in cross section, and bearing short and highly eroded Ancient South Arabian inscriptions. Surface pottery on the Wadi Matar sites in general mainly comprised fragments of red or brown mineral-tempered ware, with a dark grey core and brown burnished surfaces. These included the everted rims of jars and bowls, large rims of bowls or basins, horizontal and vertical handle fragments, and ring bases. They might be ascribed broadly to the ancient South Arabian period. One or possibly two everted rim fragments of an orange ware with dark-grey core were comparable to Aksumite cooking pots dating to the Aksumite 3 phase (AD 350-550) (Andrea Manzo, pers. comm.). Other imports included pink-ware sherds with horizontal ribs and external yellow slip. One rim fragment of pink ware had an external green-yellow surface. Both these could belong to Byzantine amphorae (Cooper and Zazzaro, forthcoming). At Wadi Matar $H \bar{a}^{\circ}$, just $60 \mathrm{~m}$ north of site $B \bar{a}^{\circ}$, fragments of the body and bifid handle of a Dressel 2-4 amphora from Campania, Italy (late 1st-century BC-79 AD) were also found (Keay and Williams, 2005).

The only site on the plateau with indicators of later occupation was Wadi Matar South, some $750 \mathrm{~m}$ south of Wadi Matar $B \bar{a}^{\text {}}$. Here, sherds of Islamic and early-modern pottery were found in addition to Byzantine red-ware and turquoise-glazed wares of potentially broad date.

\section{Discussion}

The efficacy of the Wadi Matar anchor is based on its large size and weight, and on the two flukes, now absent, near the base that would have gripped rocks or penetrated seabed sediments. The anchor's large dimensions also suggest it was intended for a large vessel, on which it could have been used either as an anchor or, on occasion, as ballast. The manufacture and the appearance of the anchor do not compare to other anchors reported elsewhere to date: this, together with the fact that a local stone has been used, suggests an indigenous or regional technology.

The dating of stone anchors is notoriously difficult, since they often occur as isolated finds, often under water, with no associable archaeological material. The use of anchors with three holes is at attested earliest in the eastern Mediterranean in the Bronze Age (Shaw 1995), and occurs in many locations around the world until modern times, including locations around the Indian Ocean (Gaur, et al., fig. 20; Sila Tripati and Gaur, 1997; Sundaresh et al., 1999; Vosmer, 1999, fig. 3). Within the Red Sea, two three-holed stone anchors - both smaller in dimensions than the Wadi Matar anchor - were found associated with the Naama shipwreck, which dates to the late 13th or early 14th century AD (Raban 1972-75 and 1990: 299-302). 
However, a typological comparison of the Wadi Matar anchor with others over a wider geographical area suggests an extremely broad date for it from between the Bronze Age and the Medieval period, rather than modern (see, for example, Grossmann and Kingsley 1996: 50-52). Notwithstanding its surface context, the occurrence of this anchor on land in association with a particular archaeological settlement site allows us tentatively to propose a pre-Islamic date for it, based on the preliminary indications of surface pottery finds.

How the anchor ended up at a site over $2.6 \mathrm{~km}$ from the sea is as yet a matter for speculation. Sea levels have changed little in the period under consideration. The strand plain to the south of the fossil-coral plateau on which the anchor stands does show signs of progradation, but even assuming the total absence of this plain during antiquity, the anchor would still have been deposited almost $2 \mathrm{~km}$ from the sea. It is conceivable that the find location reflects a reuse of one of the doorposts of Wadi Matar $B \bar{a}^{\circ}$, the post having been extracted and worked into its anchor form following the abandonment of the building in question. The implication of this interpretation is that the object might never have left the site, or have been used as an anchor. An alternative interpretation is that the object was transported to the site for some purpose. Given the plentiful supply of coral-stone on the plateau, it is unlikely to have been brought there as crude building material. Whether made on site or brought there, the possible ritual meaning of the anchor in this location should be considered.

It is not unprecedented to find stone anchors inland, often in Bronze-Age ritual contexts, and there are parallels around the western Indian Ocean and Eastern Mediterranean (Wachsmann 1998: 258-273). Stone anchors from the period have been found re-used with ritual significance in the temples of Ras Shamra in Syria and Byblos in Lebanon (Frost 1969 and 1991); in the Red Sea at the Egyptian Pharaonic site of Mersa Gawasis (Zazzaro and Abdel Maguid 2006 and Zazzaro and Abdel Maguid, forthcoming); and in the Gulf, in the courtyard of the second temple of Barber in Bahrain (Mortensen 1986: 184), as well as at Tell Sa'd in Kuwait (Vine and Casey 1992: 21). The Wadi Matar anchor should also be considered in the light of these comparisons.

John P. Cooper and Chiara Zazzaro

The MARES Project,

Institute of Arab and Islamic Studies,

University of Exeter

United Kingdom 


\section{Acknowledgements}

The Farasan Islands survey was conducted at the invitation of Professor Ali al-Ghabban, vice president of the Saudi Commission for Tourism and Antiquities (SCTA), with the local assistance of SCTA colleagues Dr Faisal al-Toumaihi and Mr Abdo Isa Aqili. It was part of the University of Exeter's MARES Project, led by Professor Dionisius A. Agius. The MARES team included Ms Lucy Semaan, a Ph.D student, who helped draw the anchor. MARES was funded by the Golden Web Foundation, and the fieldwork was further suported by the Seven Pillars of Wisdom Trust, with substantial logistical support from the SCTA.

\section{References}

Agius, D.A., Cooper, J.P., Semaan, L., and Zazzaro, C., forthcoming, The Mares Project survey of Jizan and the Farasan Islands Atlal.

Bailey, G.N., Flemming N., King, G.C.P., Lambeck, K., Momber, G., Moran, L., A1Sharekh, A., and Vita-Finzi, C., 2007a, Coastlines, submerged landscapes, and human evolution: the Red Sea Basin and the Farasan Islands, Journal of Island and Coastal Archaeology 2.2, 127 60.

Bailey, G. N., Al Sharekh, A., Flemming N., Lambeck, K., Momber, G., Sinclair, A. and Vita-Finzi, C., 2007b, Coastal prehistory in the southern Red Sea Basin: underwater archaeology and the Farasan Islands, Proceedings of the Seminar for Arabian Studies 37, 116.

Cooper, J.P., and Zazzaro, C., forthcoming, The Mares Project survey of Jizan and the Farasan Islands, Part II: Archaeology, Atlal.

Davies, S., and Morgan, E., 2002, Red Sea Pilot. St Ives, Cambridgeshire.

Frost, H., 1969, The Stone Anchor of Byblos, Mélanges de l'Université Saint-Joseph 45, 425442.

Frost, H., 1991, Anchors sacred and profane. Ugarit-Ras Shamra, 1986; the stone anchors revised and compared, in M. Yon (ed.), Ras Shamra-Ougarit VI: Arts et Industries de la Pierre, 355-410. Paris.

Gaur, A. S., Sundaresh, Sila Tripati, Gudigar, P., Vora, K. H., and Bandodker, S.N. , 2001, A group of 20 stone anchors from the waters of Dwarka, on the Gujarat Coast, India, International Journal of Nautical Archaeology 30.1, 95-108. 
Grossmann, E. and Kingsley, S. A., 1996, A three-hole stone anchor with wood remains from Crusader Arsuf (Apollonia), Israel, International Journal of Nautical Archaeology 25.1, 4954.

Hall, M., Llewellyn, O.A., Miller, A.G., al-Abbasi, T.M., al-Wetaid, A.H., al-Harbi, R.J., and al-Shammari, K.F., 2010, Important Plant Areas in the Arabian Peninsula: 2. Farasan Archipelago, Edinburgh Journal of Botany 67.2, 189-208.

Keay, S. and Williams, D., 2005, Roman Amphorae: a digital resource, University of Southampton, doi:10.5284/1000021.

Marion de Procé, S. and Phillips, C., 2010, South Arabian inscriptions from the Farasān Islands (Saudi Arabia), Proceedings of the Seminar for Arabian Studies 40, 277-82. Mortensen, P., 1986, The Barbar Temple: Its Chronology and Foreign Relations Reconsidered, in S. H. Al Khalifa and M. Rice (eds), Bahrain Through the Ages: the Archaeology, London and New York.

Phillips, C., Villeneuve, F., and Facey, W. A. 2004, A Latin Inscription from South Arabia. Proceedings of the Seminar for Arabian Studies 34, 239-50.

Raban, A., 1972-75, The "Naamah-south" expedition. Sefunim, IV, 33-9.

Raban, A., 1990, Medieval anchors from the Red Sea, International Journal of Nautical Archaeology 19.4, 299-306.

Shaw J. W., 1995, Two three-holed stone anchors from Kommos, Crete: their context, type and origin, International Journal of Nautical Archaeology 24.4, 279-291.

Sila Tripati and Gaur, A.S., 1997, Stone anchors from Sindhudurg Fort on the west coast of India, International Journal of Nautical Archaeology 26.1, 51-57.

Sundaresh, Gaur, A.S., Gudigar, P., Tripati Sila and Vora K. H., and Bandodker S. N., 1999, Stone anchors from the Okhamandal Region, Gujarat Coast, India, International Journal of Nautical Archaeology 28.3, 229-252.

Tibbets, G.R., 1971, Arab Navigation in the Indian Ocean before the Coming of the Portuguese. London.

Van Hecke, J., Bossue, B., De Buck, V., and Carpentier, E., (eds), 1861, Acta Sanctorum X Octobris die vigesima quarta. Brussels.

Villeneuve, F., 2004, Une inscription latine sur l'archipel Farasân, Arabie Séoudite, Sud de la mer Rouge, Comptes rendus de l'Académie des Inscriptions et Belles-Lettres, 419-29. 
Villeneuve, F., 2007a, L'armée romaine en mer Rouge aux IIe-IIIe siècles après J.-C.: à propos des inscriptions de Farasân, in Lewin A. (ed.), Proceedings of the Conference L'esercito romano tardo-antico nel Vicino Oriente, Universita della Basilicate, PotenzaMatera, 12-15 May 2005, 13-27, Oxford.

Villeneuve, F., 2007b, Farasan Latin inscriptions and Bukharin's ideas: no pontifex Herculis! and other comments, Arabia 4, 289-96.

Villeneuve, F., 2008, Deux inscriptions militaires latines découvertes aux îles Farasan (mer Rouge méridionale, Arabie saoudite). Rome, Alexandrie, Pétra et le commerce oriental au IIe siècle après J.-C, in Proceedings of the Conference 'The City in the Arab World in Light of Archaeological Discoveries', Sakaka, 5-7 December 2005, 167-180. Riyadh.

Villeneuve, F., Phillips, C., and Facey, W., 2004, Une inscription latine de l'archipel Farasan (sud de la mer Rouge) et son contexte archéologique et historique, Arabia 2, 143-90.

Vine, P., and Casey, P., 1992, Kuwait: A Nation's Story, London.

Wachsmann, S., 1998, Seagoing Ships and Seamanship in the Bronze Age Levant, College Station, Texas, and London.

Vosmer, T., 1999, Indo-Arabian stone anchors in the western Indian Ocean and Arabian Sea, Arabian archaeology and epigraphy 10, 248-263.

Zarins J., Murad, A., and Al-Yaish K., 1981, Part I(a): The Second Preliminary Report on the Southwestern Province, Atlal 5, 9-42.

Zazzaro, C., and Abd el Maguid, M. M., 2006, Ancient Egyptian anchors: new results from Wadi Gawasis, in E. el-Saeed, E. Mahfuz and A. M. Megahed (eds.), Festschrift Volume presented to Prof. Abdel Monem Abdel Haleem Sayed, Alexandria, 139-62.

Zazzaro and Abdel Maguid, forthcoming, Ancient Egyptian stone anchors from Mersa Gawasis, Proceedings of the Conference The Red Sea in Pharaonic Times. Recent Discoveries along the Red Sea Coast. Cairo - Ayn Soukhna. 11-12 Jan 2009. Bulletin de l'Institut français d'archéologie orientale. 